Journal of Social Sciences 6 (1): 64-73, 2010

ISSN 1549-3652

(C) 2010 Science Publications

\title{
Can Quality of Work Life Affect Work Performance among Government Agriculture Extension Officers? A Case from Malaysia
}

\author{
${ }^{1}$ M.S. Hayrol Azril, ${ }^{1}$ U. Jegak, ${ }^{1}$ M. Asiah, ${ }^{2}$ A. Noor Azman, ${ }^{1}$ A.S. Bahaman, \\ ${ }^{1} \mathrm{O}$. Jamilah and ${ }^{3} \mathrm{~K}$. Thomas \\ ${ }^{1}$ Laboratory of Rural Advancement and Agriculture Extension, \\ Institute for Social Science Studies, University Putra Malaysia, Malaysia \\ ${ }^{2}$ Department of Management and Marketing, Faculty of Economics and Management, \\ University Putra Malaysia, Malaysia \\ ${ }^{3}$ Department of Professional Development and Continuing Education, \\ Faculty of Educational Studies, University Putra Malaysia, Malaysia
}

\begin{abstract}
Problem statement: The importance of agriculture industry in enhancing the country economy cannot be denied. Recently, a total of USD 1.7 billion has been allocated by the government to boost this industry. Beside of this huge allocation, do the policy implementers which are the agriculture extension officers have adequate work performance to carry out the responsibility given to them? Approach: This study would like to discover whether quality of work life among the agriculture extension employee do have impact their work performance or not. It is necessary to estimate quality of work life function in enhancing work performance, analyze the most important factor and variables on this work performance. The instruments used for collecting data were: A scale on individual and family life, a scale on safety and security on the organization, a scale on interpersonal relationship in the organization, a scale on job satisfaction, a scale on organizational policies and management style, a scale on personnel health and well being, a scale on work environment, a scale on remuneration and a scale on organizational support. The data were analyzed PASW software. Results: Results depict that all of the nine qualities of work life studied have significant and positive relationship with work performance where the highest relationship occurred between individual and family life with work performance. Multiple regression analysis demonstrated that five factors which are individual and family life, job satisfaction, organization policy and management style, work environment and remuneration are the main contributors to work performance among government agricultural extension employees. Conclusion/Recommendations: From the results gained, it can be concluded that aspect of individual and family life is the highest contributor to work performance among government agriculture extension officer. It can be noted that more courses on how to manage individual and family life should be intensified. A specific counseling department should be established within agriculture agencies in Malaysia. From this study, it is recommended for the future researchers to investigate more on the influence of individual and family life on work performance and work satisfaction in Malaysia.
\end{abstract}

Key words: Quality of work life, government agriculture extension officers and work performance

\section{INTRODUCTION}

Malaysia is often acknowledged as one of the front runners in implementing agriculture development programs. Agriculture has been used intensively as one of the main devices to uplift the economy of the country for more than half a century. In The Ninth Malaysia Plan (RMK-9), it has been planned to be used as a catalyst to boost the economy sector, while recently through the Malaysia 2010 budget, almost USD 2 billion has been allocated for agriculture sector. This huge allocation is hoped to develop the agriculture sector as one of the pertinent industries for this country. To ensure the success of this plan, it is also important to have quality implementers, which is the government Agriculture Extension Employee (AAE).

Corresponding Author: Hayrol Azril Mohamed Shaffril, Laboratory of Rural Advancement and Agriculture Extension, Institute for Social Science Studies, University Putra Malaysia, 43400 Serdang, Selangor Darul Ehsan, Malaysia 
Their work performance is indeed one of the fundamental determinants for the success of this sector. There are a number of agriculture agencies in Malaysia. The main agency, which is the Ministry of Agriculture and Agro-Based Industry (MAAI), plays the vital role in implementing the policies determined by the government. Under MAAI, there are a number of agriculture departments, institutes and boards such as Department Of Agriculture (DOA), Department Of Fisheries (DOF), Malaysian Agriculture Research and Development Institute (MARDI) and Malaysian Palm Oil Board (MPOB), each plays a significant and specific roles determined by MAAI. AAE are among 1.2 million government employees in Malaysia who hold the responsibility of servicing the community especially the agriculture community. The main query that can be raised here, is the work performance of AAE adequate enough to carry out the responsibility given to them? Does the Quality Of Work Life (QOWL) affect their work performance? This study will provide the answer.

In order to gain better understanding of the relationship between QOWL and work performance, there are abundance number of literature that try to summarize the connection between these two important elements. In order to ensure the success of an organization, it cannot be denied that the organization "engine" which is the employee must be focused. This "engine" must be serviced accordingly to ensure that they will give their best. Employees whose needs are not fulfilled by the organization always demonstrate their dissatisfaction by performing below their actual ability. Porter and Lawler (1968) identified three types of performance. First is concerning to productivity. Second, concerning ratings of individuals by someone other than the person whose performance is being considered. Self-appraisal and self-ratings become the third type of performance. Thus, job performance measures the level of achievement of business and social objectives and responsibilities from the perspective of the judging party (Hersey and Blanchard, 1993).

There are rising literature that tries to seek the association between quality of work life and work performance. Among the main focus included in this literature is the remuneration aspect. Remuneration aspects such as salary, salary increment, bonuses, allowances, pension and medical benefits are among the best examples that can motivate employee to give their best for their employer. Studies done by Wan (2007); Martzler and Renzl (2007) and Davies et al. (2001) concluded that remuneration is an important aspect if an organization wants to see their "engine" performing their best. Remuneration also can be seen as a form of recognition from the employer to their employee. These three studies further strengthen the studies by Okpara (2004); Oshagbemi (2000) and Sloane and Williams (1996) who highlighted differences in remuneration aspects received by the employee will suddenly affect their work satisfaction and work performance.

Besides the remuneration aspect, it can be noted in the literature, interpersonal communication aspects frequently are raised as one of the main factors contributing to work performance. The interpersonal communication aspect such as respecting others, working together, believing others and information sharing if emphasized by the organization, will bring benefit to both sides, the employees and the employer. Candace et al. (2008); Daley (2003) and Madlock (2008) in their researches have concluded that interpersonal communication does have an impact on employees' work performance. Conversely, Litterst and Eyo (1982) have other view where they accentuate on interpersonal communication as a positive element that should be cultivated among the employees in order to reduce any problem that can be caused by miscommunication. Referring to Mastura et al. (2006), work satisfaction and work performance depend on hygiene and motivation factors. The important hygiene aspects are organization performance and interpersonal communication while the important motivation aspects are responsibility and job promotion.

Work environment also has been identified as one of the important determinants for work performance. Working environment such as ergonomics, recent ICTs availability, harmony environment and safety working environment will bring comfort to employees thus providing them a better environment to perform their best. Hardin (1960) in his study had noted that work environment has an impact on work performance while Darlene and Borman (1989) proved that working environment such as physical environment, office colleague, job satisfaction and management supervision can construct work performance.

It cannot be argued that job security and safety aspects can reflect employee work performance. Job security and safety aspects such as retirement scheme, workers association and accident free work place for example, can produce higher motivation among the employees in order for them to perform accordingly. A study accomplished by Luchak and Gellatly (2002) has noted that systematic and established pension scheme can enhance employees' work performance. Kim et al. (1999) has produced interesting outcomes to be shared where they concluded that aspect such as free accident work place is indeed an important key to intensify 
employees work performance. Another study by Vloisky and Aguilar (2009) emphasized that stable and secured job have significant and positive relationship with employee work performance.

Based on the previous studies, organization policy and management style found to have influence on work performance. Organization policy and management style that put so much pressure on their employees are not encouraged as it can create negative acceptation of the policy among the employees. It can lessen the motivation, increase turnover possibility and resulting the employee opting for other organization as their new employer. This is indeed demonstrated by a study by Keiningham et al. (2006) where they noted that among the aspects expected by employee in their organization policy are fair organization policy and systematic management style. Organization support is also an important tool to strengthen employee work performance. Employer should be reminded that if their "main engine" is left working alone without any support or supervision, their performance will be less thus affects the quality of their productivity. This is not surprising as it is in tandem with studies done by Phattanacheewapul and Ussahawanitchakit (2008) and Hutchinson and Garstika (2006).

Individual and family life is another important driver for employee work performance and this is proved through studies accomplished by Mazerolle et al. (2008); Mulvaney et al. (2006) and Ezra and Deckman (1996). In their studies, it can be seen that stable individual and family life will produce higher work performance among employee. Unstable individual and family life were found to cause unstable emotions thus bring negative impact to the work performance. Personal health and well being were found to have influence on employees work performance. Piqueras (2006) in his study focused on the significant relationship between this aspect and employee work performance. It cannot be denied that aspects such as personal health, stress, personal problems, physical fitness and personal happiness are important for employee. Vanhala and Tuomi (2006) in their study have found association between work performance and personal well being, human resource management and work satisfaction.

\section{MATERIALS AND METHODS}

A total of 180 government Agriculture Extension Officers (AAE) were chosen as respondents for this study (Table 1). Due to the main criteria selection, which was selecting department that practice work systems such as International Standard Organization (ISO) and Key Performance Index (KPI),
Table 1: Selected agriculture agencies

\begin{tabular}{lll}
\hline Organization & Frequency & Percentage \\
\hline $\begin{array}{l}\text { Malaysian Agriculture Research and } \\
\text { Development Institute (MARDI) }\end{array}$ & 53 & 29.4 \\
$\begin{array}{l}\text { Department of Agriculture (DOA) } \\
\text { Malaysian Timber Board Industry (MTIB) }\end{array}$ & 27 & 15.0 \\
$\begin{array}{l}\text { Department of Fisheries (DOF) } \\
\text { Malaysian Pineapple Industry Board }\end{array}$ & 18 & 11.7 \\
(LPNM) & 14 & 7.0 \\
$\begin{array}{l}\text { Malaysian Fisheries Development Board } \\
\text { (LKIM) }\end{array}$ & 11 & 6.1 \\
$\begin{array}{l}\text { Malaysian Rubber Board (LGM) } \\
\text { Malaysian Palm Oil Board (MPOB) }\end{array}$ & 10 & 5.6 \\
$\begin{array}{l}\text { Federal Agriculture Marketing Authority } \\
\text { (FAMA) }\end{array}$ & 9 & 5.0 \\
Farmers Authority Organization (FOA) & 8 & 5.0 \\
\hline
\end{tabular}

only 200 respondents were selected. Twenty questionnaires were excluded due to some incomplete data. The sampling procedure used here was stratified random sampling. The data collection process for this study was completed in the period of two months whereby drop and pick method was used. The questionnaire was earlier pre tested to test its reliability and validity. The pre test process was done on 30 University Putra Malaysia staff.

The independent variables for this study are the nine aspects of Qualities Of Work Life (QOWL) which are remunerations, job satisfaction, interpersonal relationship, work environment, work environment, organizational support, organizational policies and management style, safety and security, individual and family life and personnel health and well being. The dependent variable for this study is AAE work performance. For the purpose of analysis, PASW software was used where descriptive and inferential analyses were employed. Descriptive statistics such as frequency, percentage, mean and standard deviation were utilized to summarize the demographic data of the AAE. For determining any relationship between QOWL and work performance, analyses such as Pearson Correlation and Multiple Linear Regression were employed.

\section{RESULTS AND DISCUSSION}

Respondents socio-demographic profile: Before we go to the main objective of this study, it is better for us to get a clear picture of the respondents studied. Based on the results depicted in Table 2, it can be concluded that majority of the respondents are male $(57.2 \%)$, age $<40$ years $(58.9 \%)$, married (78.3\%), posses Diploma or certificates as their highest education achievement (38.4\%), among the support staff $(77.8 \%)$, receive between RM1501-2500 a month (45.0\%), have 15 years of working experience (34.4\%), working in State of Selangor (39.4\%), able to buy their own house $(56.1 \%)$ and live in the range between $1-10 \mathrm{~km}$ from their home to their office. 
Table 2: Respondents socio-demographic profile $(\mathrm{n}=180)$

\begin{tabular}{|c|c|c|c|}
\hline Variables & Frequency & Percentage & Mean SD \\
\hline \multicolumn{4}{|l|}{ Gender } \\
\hline Female & 103.0 & 57.2 & \\
\hline Male & 77.0 & 42.8 & \\
\hline Age & 37.4 & 11.2 & \\
\hline$<40$ years & 105.0 & 58.9 & \\
\hline$>40$ years & 75.0 & 41.1 & \\
\hline \multicolumn{4}{|l|}{ Marital status } \\
\hline Married & 141.0 & 78.3 & \\
\hline $\begin{array}{l}\text { Unmarried/ } \\
\text { widow/widower }\end{array}$ & 39.0 & 21.7 & \\
\hline \multicolumn{4}{|l|}{ Education attainment } \\
\hline Post graduate/degree & 51.0 & 28.3 & \\
\hline Diploma/Certificate & 69.0 & 38.4 & \\
\hline School leaver & 60.0 & 33.3 & \\
\hline \multicolumn{4}{|l|}{ Job category } \\
\hline Management staff & 40.0 & 22.2 & \\
\hline Support staff & 140.0 & 77.8 & \\
\hline Salary (value in ringgit & $2,486.9$ & 1318.5 & \\
\hline \multicolumn{4}{|l|}{ Malaysia) } \\
\hline$<1500$ & 40.0 & 22.2 & \\
\hline $1501-2500$ & 81.0 & 45.0 & \\
\hline $2501-3500$ & 30.0 & 16.7 & \\
\hline$>3501$ & 29.0 & 16.1 & \\
\hline Working experience & 14.7 & 12.8 & \\
\hline $1-5$ years & 62.0 & 34.4 & \\
\hline $6-15$ years & 43.0 & 23.9 & \\
\hline $16-25$ years & 23.0 & 12.8 & \\
\hline$>26$ years & 52.0 & 28.9 & \\
\hline \multicolumn{4}{|l|}{ State } \\
\hline Selangor & 71.0 & 39.4 & \\
\hline Kuala Lumpur & 50.0 & 27.8 & \\
\hline Putrajaya & 45.0 & 25.0 & \\
\hline Johor & 14.0 & 7.5 & \\
\hline \multicolumn{4}{|l|}{ Type of residential } \\
\hline Government quarters & 25.0 & 13.9 & \\
\hline Owned & 101.0 & 56.1 & \\
\hline Rent & 54.0 & 30.0 & \\
\hline $\begin{array}{l}\text { Distance to work } \\
\text { place (from home) }\end{array}$ & 18.2 & 13.6 & \\
\hline $1-10 \mathrm{~km}$ & 66.0 & 36.7 & \\
\hline $11-20 \mathrm{~km}$ & 50.0 & 30.0 & \\
\hline$>21 \mathrm{~km}$ & 54.0 & 33.3 & \\
\hline
\end{tabular}

The percentage of those who receive salary below RM1500 (22.0\%), raise some concerns. Even though there are quit a big number on those who receive low salary, the percentage on those who are able to buy their own houses are very encouraging $(56.1 \%)$. One of the possible reasons that lead to this is the ease of procedure in obtaining housing loan by AAE. On top of it, the government recently has announced that the government employees have the options to choose either to have their pension at the age of 56 or 58 which lowered the monthly payment cost of their housing loan thus increasing their financial ability to buy their own house. AAE found to admit the importance of education on their work where a total of $66.7 \%$ of them found to posses university certificates such as diploma, degree, master or PhD.
Table 3: Level of work performance among AAE $(\mathrm{n}=180)$

\begin{tabular}{lclll}
\hline Level & Frequency & Percentage & Mean & SD \\
\hline & 7.84 & 1.27 & & \\
Low (0-3.33) & - & - & & \\
Moderate (3.34-6.67) & 28.00 & 15.6 & & \\
High (6.68-10) & 152.00 & 84.4 & & \\
\hline
\end{tabular}

Table 4: Work quantity $(\mathrm{n}=180)$

\begin{tabular}{lclll}
\hline Level & Frequency & Percentage & Mean & SD \\
\hline & 7.73 & 1.32 & & \\
Low (0-3.33) & - & - & & \\
Moderate (3.34-6.67) & 32 & 17.8 & & \\
High (6.68-10) & 148 & 82.2 & & \\
\hline
\end{tabular}

Work performance: In order to reveal the level of work performance among AAE, four aspects which are work quantity, work quality, punctuality and work system have been emphasized. Table 3 depicts the overall level of work performance among AAE. The value was gained by cumulative value of the four aspects. It can be concluded that the overall work performance among AAE is at high level based on the mean score of 7.84 (from maximum 10.0).

Work quantity: Table 4 presents the level of work quantity of the AAE studied. More than four fifth of the AAE $(82.2 \%)$ posses high level of work quantity, thus give an early prediction that AAE in Malaysia are productive in their job. Less than one fifth of the AAE $(17.8 \%)$ posses' moderate level of work quantity. It is interesting to know that none of the AAE who respond to the questionnaire have low level of work quantity thus supporting the early prediction that $\mathrm{AAE}$ in Malaysia is productive in their job.

The results of analysis done is showed in Table 5 and it can be seen that statement of "I always achieve the quantity of customer demand" recorded the highest mean score $(M=7.80)$. There is a possibility that there is a higher customer satisfaction within these agencies due to positive response towards their demand. The lowest mean score recorded by statement "I always achieve the team work objectives" $(M=7.70)$. Even though it is the lowest, but the difference between the highest mean score and the lowest is just .10.

Work quality: Based on the overall mean score recorded for work quality aspect $(\mathrm{M}=7.98)$, it can be noted that AAE recorded a good score on the work quality aspects. A total of $151 \mathrm{AAE}$ or $83.9 \%$ posses high level of work quality thus it proves that besides of having the ability of being productive, AAE in Malaysia also have the quality on the job produced. A total of $16.1 \%$ were found to have moderate level of work quality while none of them posses low level of work quality. 
Table 5: Percentage on work quantity statements $(n=180)$

\begin{tabular}{|c|c|c|c|c|c|c|c|c|c|c|c|c|}
\hline \multirow[b]{2}{*}{ Statement } & \multicolumn{10}{|c|}{ Score percentage } & \multirow[b]{2}{*}{ Mean } & \multirow[b]{2}{*}{ SD } \\
\hline & 1 & 2 & 3 & 4 & 5 & 6 & 7 & 8 & 9 & 10 & & \\
\hline $\begin{array}{l}\text { I always achieve the quantity } \\
\text { of customers' demand }\end{array}$ & - & - & - & 1.7 & 6.1 & 10.6 & 16.1 & 32.8 & 23.3 & 9.4 & 7.80 & 1.41 \\
\hline $\begin{array}{l}\text { I always achieve my personal } \\
\text { work objectives }\end{array}$ & - & - & 0.6 & 1.1 & 6.1 & 10.6 & 18.9 & 33.3 & 22.2 & 7.2 & 7.71 & 1.38 \\
\hline $\begin{array}{l}\text { I always achieve the } \\
\text { organizational goals }\end{array}$ & - & - & - & 1.7 & 6.1 & 8.9 & 20.6 & 33.9 & 22.8 & 6.1 & 7.71 & 1.33 \\
\hline $\begin{array}{l}\text { I always achieve the } \\
\text { team work objectives }\end{array}$ & - & - & - & 2.8 & 4.4 & 9.4 & 23.9 & 28.9 & 23.9 & 6.7 & 7.70 & 1.37 \\
\hline \multicolumn{12}{|l|}{ Table 6: Work quality $(\mathrm{n}=180)$} & SD \\
\hline & \multicolumn{3}{|c|}{7.98} & & \multicolumn{2}{|c|}{1.30} & & & & & & \\
\hline Low $(0-3.33)$ & \multirow{2}{*}{\multicolumn{3}{|c|}{$\begin{array}{c}- \\
29.00\end{array}$}} & & \multirow{2}{*}{\multicolumn{2}{|c|}{-}} & & & & & & \\
\hline Moderate (3.34-6.67) & & & & & \multirow{2}{*}{\multicolumn{2}{|c|}{$\begin{array}{l}10.1 \\
83.9\end{array}$}} & & & & & & \\
\hline High $(6.68-10)$ & \multicolumn{3}{|c|}{151.00} & & & & & & & & & \\
\hline
\end{tabular}

Table 7: Percentage on work quality statements $(\mathrm{n}=180)$

\begin{tabular}{|c|c|c|c|c|c|c|c|c|c|c|c|c|}
\hline \multirow[b]{2}{*}{ Statement } & \multicolumn{10}{|c|}{ Score percentage } & \multirow[b]{2}{*}{ Mean } & \multirow[b]{2}{*}{ SD } \\
\hline & 1 & 2 & 3 & 4 & 5 & 6 & 7 & 8 & 9 & 10 & & \\
\hline I strive for work excellence & - & - & 0.6 & 1.1 & 4.4 & 8.3 & 10.0 & 24.4 & 33.9 & 17.2 & 8.21 & 1.46 \\
\hline $\begin{array}{l}\text { I have always ensured continual } \\
\text { improvements on my works }\end{array}$ & - & - & - & 1.1 & 6.7 & 5.6 & 9.4 & 30.0 & 32.8 & 14.4 & 8.17 & 1.41 \\
\hline $\begin{array}{l}\text { I have always responded to } \\
\text { customer }\end{array}$ & - & - & - & 1.1 & 5.6 & 8.3 & 13.3 & 29.4 & 28.3 & 13.9 & 8.05 & 1.41 \\
\hline $\begin{array}{l}\text { complaints accordingly } \\
\text { In general, my job performance } \\
\text { measures up to expected quality }\end{array}$ & - & - & - & 1.1 & 6.7 & 5.6 & 13.9 & 26.1 & 38.9 & 7.80 & 8.05 & 1.35 \\
\hline $\begin{array}{l}\text { I have always fulfilled } \\
\text { customer needs }\end{array}$ & - & - & 0.6 & 0.6 & 7.2 & 6.7 & 19.4 & 30.6 & 27.8 & 7.20 & 7.82 & 1.37 \\
\hline I always work systematically & - & - & - & 1.7 & 6.7 & 8.3 & 17.2 & 33.9 & 23.9 & 8.30 & 7.80 & 1.38 \\
\hline I do my work with accuracy & - & 0.6 & 1.1 & 6.7 & 7.8 & 20.6 & 31.1 & 31.1 & 25.0 & 7.20 & 7.76 & 1.39 \\
\hline \multicolumn{13}{|l|}{ Table 8: Punctuality $(\mathrm{n}=180)$} \\
\hline Level & \multicolumn{3}{|c|}{ Frequency } & & \multicolumn{3}{|c|}{ Percentage } & \multicolumn{3}{|c|}{ Mean } & & SD \\
\hline & \multicolumn{3}{|c|}{7.94} & & \multicolumn{2}{|r|}{1.40} & & & & & & \\
\hline Low $(0-3.33)$ & \multirow{2}{*}{\multicolumn{3}{|c|}{32.00}} & & \multicolumn{2}{|r|}{-} & & & & & & \\
\hline Moderate (3.34-6.67) & & & & & \multirow{2}{*}{\multicolumn{2}{|c|}{$\begin{array}{l}17.8 \\
822\end{array}$}} & & & & & & \\
\hline High $(6.68-10)$ & \multicolumn{3}{|c|}{148.00} & & & & & & & & & \\
\hline
\end{tabular}

Results revealed in Table 7 found that the statement of "I strive for work excellence" recorded the highest mean score $(\mathrm{M}=8.21)$ thus it gives an early prediction that AAE are committed towards the tasks given to them. This is followed by the statement of "I have always ensured continual improvements on my works" ( $\mathrm{M}=8.17)$. Two statements recorded the third highest mean score which are "I have always responded to customer complaints accordingly" and "In general, my job performance measure up to expected quality" $(\mathrm{M}=8.05)$.

Punctuality: Table 8 narrates the punctuality possessed by AAE in delivering and completing tasks and duties given to them. Earlier, Table 4 and 6 concluded that the level of work quality and work quantity among AAE in Malaysia is very encouraging, but can the tasks assigned to AAE accomplished within the specific time given to them? Table 8 provides the answer. Based on the overall mean score obtained $(\mathrm{M}=7.94)$ and majority of the AAE (82.2\%), were found to punctually submit the tasks given to them, this study noted that AAE not only are able to fulfill the expectation of delivering high level of work quantity and work quality but also able to meet the specific date in accomplishing the tasks given to them.

Six items have been selected to construct the punctuality aspects. Data presented in Table 9 signals that the statement of "I always do my job according to stipulated time" recorded the highest mean score 
$(\mathrm{M}=8.03)$. This is followed by the statement of "I always make decision promptly when necessary" $(\mathrm{M}=7.97)$. The lowest mean score was scored by the statement of "I always delivered my work on time" $(M=7.89)$. It can be seen that even though it is the lowest, but there is only a slight difference between the highest mean score and the lowest mean score which is 0.14 .

Work systems: Systematic work can be the main determinant of any success. To have a good work system is a must for an organization in order for them to strive for excellence. The main question should be raised here is do AAE perceived positively the work systems designated to them? Table 10 provides us the answer. A total of $78.9 \%$ of AAE have high perception on work systems while $20.6 \%$ of AAE were found to have moderate perception on work systems. Only $0.6 \%$ AAE have low perception on work systems. The overall mean score recorded for work systems aspect is 7.57.

Table 11 narrates the percentage recorded by each of the statement prepared to measure perception on work systems. The range of overall mean score recorded for all the statements range from 7.49-7.68 (from maximum 10.0) based on this it can be concluded that all of these statements recorded high mean score. The highest mean score is the statement of "the work system fulfills the customer's requirement” ( $\mathrm{M}=7.68)$ thus it can be noted that AAE are able to adapt the established work system in their work. AAE also perceived that the work system would support them in achieving the mission and vision of the organization $(\mathrm{M}=7.59)$ and accomplishing their teamwork objectives $(\mathrm{M}=7.52)$.

Quality Of Work Life (QOWL) among AAE: The next discussion is identifying the level of quality of work life among AAE. On this part, each aspect of QOWL will be mentioned further on its level. To construct QOWL, nine aspects has been selected which are individual and family life, safety and security in the organization, interpersonal relationship in the organization, job satisfaction, organizational policies and management style, personal health and well being, work environment, remuneration and organizational support.

Each of the aspect was constructed by number of items. Table 12 explains the number of items representing each of the QOWL aspect. On each of the items, AAE were asked to indicate their answer based on the 10-likert scales ranging from 1 (very low) to 10 (very high). To get the mean score of each of the QOWL aspects, all of the items values were cumulated. Then, the values were divided into three levels, which are low (0-3.33), moderate (3.34-6.67) and high (6.6810.0).

Table 9: Percentage on punctuality statements $(n=180)$

\begin{tabular}{|c|c|c|c|c|c|c|c|c|c|c|c|c|}
\hline \multirow[b]{2}{*}{ Statement } & \multicolumn{10}{|c|}{ Score percentage } & \multirow[b]{2}{*}{ Mean } & \multirow[b]{2}{*}{ SD } \\
\hline & 1 & 2 & 3 & 4 & 5 & 6 & 7 & 8 & 9 & 10 & & \\
\hline I always do my job according to stipulated time & - & - & - & 1.7 & 6.1 & 6.7 & 16.7 & 27.2 & 25.6 & 16.1 & 8.03 & 1.47 \\
\hline I always make decision promptly when necessary & - & 0.6 & - & 0.6 & 6.7 & 7.8 & 16.7 & 27.8 & 25.6 & 14.4 & 7.97 & 1.49 \\
\hline I am always consistent in meeting my work targets & - & - & - & 1.7 & 6.7 & 7.8 & 15.0 & 29.4 & 27.2 & 12.2 & 7.94 & 1.45 \\
\hline I am always consistent in completing my work & - & - & 0.6 & 1.7 & 6.1 & 7.2 & 16.1 & 29.4 & 27.8 & 11.1 & 7.92 & 1.46 \\
\hline I always do my job promptly & - & 0.6 & - & 1.7 & 6.1 & 7.2 & 18.3 & 27.2 & 26.7 & 12.2 & 7.90 & 1.50 \\
\hline I always delivered my work on time & - & - & 0.6 & 1.7 & 7.2 & 8.3 & 12.8 & 30.6 & 27.8 & 11.1 & 7.89 & 1.50 \\
\hline
\end{tabular}

Table 10: Work system $(\mathrm{n}=180)$

\begin{tabular}{lccc}
\hline Level & Frequency & Percentage & Mean \\
\hline & 7.57 & 1.42 & \\
Low (0-3.33) & 1.00 & 0.60 & \\
Moderate (3.34-6.67) & 37.00 & 20.60 & \\
High (6.68-10) & 142.00 & 78.90 & \\
\hline
\end{tabular}

Table 11: Percentage on work system statements $(n=180)$

\begin{tabular}{|c|c|c|c|c|c|c|c|c|c|c|c|c|}
\hline \multirow[b]{2}{*}{ Statement } & \multicolumn{10}{|c|}{ Score percentage } & \multirow[b]{2}{*}{ Mean } & \multirow[b]{2}{*}{$\mathrm{SD}$} \\
\hline & 1 & 2 & 3 & 4 & 5 & 6 & 7 & 8 & 9 & 10 & & \\
\hline $\begin{array}{l}\text { The work system fulfills the } \\
\text { customer's requirement }\end{array}$ & 1.1 & - & - & 1.7 & 8.3 & 11.1 & 20.0 & 31.7 & 21.7 & 4.4 & 7.68 & 1.41 \\
\hline $\begin{array}{l}\text { The work system fulfills the mission } \\
\text { and vision of organization }\end{array}$ & - & 0.6 & 0.6 & 1.7 & 7.8 & 10.6 & 20.6 & 32.8 & 21.1 & 4.4 & 7.59 & 1.60 \\
\hline $\begin{array}{l}\text { The work system fulfills the team } \\
\text { work objectives }\end{array}$ & 1 & 0.6 & 1.7 & 1.7 & 8.9 & 8.9 & 16.1 & 31.1 & 24.4 & 6.7 & 7.52 & 1.45 \\
\hline $\begin{array}{l}\text { The work system fulfills my } \\
\text { personal work goals }\end{array}$ & - & - & 0.6 & 1.1 & 8.3 & 9.4 & 16.7 & 33.3 & 25.0 & 5.6 & 7.49 & 1.53 \\
\hline
\end{tabular}


Table 12: Quality of work life aspects studied

\begin{tabular}{ll}
\hline QOWL aspects & No. of items \\
\hline Individual and family life & 6 \\
Safety and security in the organization & 5 \\
Interpersonal relationship in the organization & 7 \\
Job related & 8 \\
Organizational policies and management style & 9 \\
Personal health and well being & 9 \\
Work environment & 9 \\
Remuneration & 9 \\
Organizational support & 8 \\
\hline
\end{tabular}

The mean score obtained for overall QOWL is quite impressive ( $M=6.95$, from maximum 10.0$)$, thus, it can be considered that QOWL of AAE in Malaysia is at a high level. It is interesting to discover that remuneration is not the aspect that records the highest mean score. Besides, the highest mean score recorded by individual and family life aspects $(\mathrm{M}=7.62)$. This is not surprising as it is in tandem with study done by Witt and Carlson (2006). Family is indeed an important supporter for us, probably their support are able to provide motivation and strength for the AAE to perform better in their work. The second highest mean score was recorded by safety and security in the organization aspects $(M=7.15)$. To feel safe and secured is an important determinant for enhancing work performance among employees (Spytak et al., 1999; Cascio, 1992). Safety and security aspects on job such as retirement scheme, compensation on accident at workplace, job security and job safety (e.g., Chemical free) can give a vibrant force on work performance. It is the responsibility of the employer to play the pivotal role in providing more secured and safety job for their employees. Work environment indeed can create certain feelings that will influence their work performance.

The third highest mean score recorded by the aspect of interpersonal relationship in the organization $(\mathrm{M}=7.13)$. Conversely, this portrays the important of communication aspect as a splendid mechanism for the thriving of better work performance. This is not surprising as it is pertinent with studies demonstrated by Ogunjimi et al. (2008); Goris et al. (2000) and Pettit et al. (1997) who claimed that poor interpersonal relationship did significantly affect the work performance. The lowest mean score recorded by organizational support $(\mathrm{M}=6.23)$ (Table 13).

Table 14 depicts the relationship between nine QOWL aspects and work performance. For this purpose, inferential analysis using Pearson Correlation was employed. From the results presented, it can be clarified that all of the nine QOWL aspects have positive and significant relationship with work performance. The data gained here bring us to a clearer picture that all these nine QOWL aspects have something to do with work performance.
Table 13: Level of QOWL among AAE $(\mathrm{n}=180)$

\begin{tabular}{|c|c|c|c|c|}
\hline QOWL Aspect & Frequency & Percentage & Mean & SD \\
\hline Overall QOWL & & & 6.95 & 1.20 \\
\hline Low $(0-3.33)$ & 1 & 0.6 & & \\
\hline Moderate (3.34-6.67) & 62 & 34.4 & & \\
\hline High $(6.68-10.0)$ & 117 & 65.0 & & \\
\hline Individual and family life & & & 7.62 & 1.42 \\
\hline Low $(1.0-3.33)$ & 1 & 0.6 & & \\
\hline Moderate (3.34-6.67) & 35 & 19.4 & & \\
\hline $\operatorname{High}(6.68-10.0)$ & 144 & 80.0 & & \\
\hline $\begin{array}{l}\text { Safety and security in the } \\
\text { organization }\end{array}$ & & & 7.15 & 1.54 \\
\hline Low $(1.0-3.33)$ & 4 & 2.2 & & \\
\hline Moderate (3.34-6.67) & 52 & 28.9 & & \\
\hline $\operatorname{High}(6.68-10.0)$ & 124 & 68.9 & & \\
\hline $\begin{array}{l}\text { Interpersonal relationship } \\
\text { in the organization }\end{array}$ & & & 7.13 & 1.58 \\
\hline Low $(1.0-3.33)$ & 3 & 1.7 & & \\
\hline Moderate (3.34-6.67) & 53 & 29.4 & & \\
\hline High (6.68- 10.0) & 124 & 68.9 & & \\
\hline Job satisfaction & & & 7.09 & 1.42 \\
\hline Low $(1.0-3.33)$ & 4 & 2.2 & & \\
\hline Moderate (3.34-6.67) & 48 & 26.7 & & \\
\hline High $(6.68-10.0)$ & 128 & 71.1 & & \\
\hline $\begin{array}{l}\text { Organizational policies and } \\
\text { management style }\end{array}$ & & & 7.07 & 1.85 \\
\hline Low $(1.0-3.33)$ & 8 & 4.5 & & \\
\hline Moderate (3.34-6.67) & 60 & 33.3 & & \\
\hline High $(6.68-10.0)$ & 112 & 62.2 & & \\
\hline $\begin{array}{l}\text { Personal health and well } \\
\text { being }\end{array}$ & & & 6.85 & 1.21 \\
\hline Low $(1.0-3.33)$ & 2 & 1.1 & & \\
\hline Moderate (3.34-6.67) & 66 & 36.7 & & \\
\hline High $(6.68-10.0)$ & 112 & 62.2 & & \\
\hline Work environment & & & 6.76 & 1.45 \\
\hline Low $(1.0-3.33)$ & 2 & 1.1 & & \\
\hline Moderate (3.34-6.67) & 78 & 43.3 & & \\
\hline High $(6.68-10.0)$ & 100 & 56.6 & & \\
\hline Remuneration & & & 6.65 & 1.57 \\
\hline Low $(1.0-3.33)$ & 3 & 1.7 & & \\
\hline Moderate (3.34-6.67) & 79 & 43.9 & & \\
\hline $\operatorname{High}(6.68-10.0)$ & 98 & 54.4 & & \\
\hline Organizational support & & & 6.23 & 1.46 \\
\hline Low $(1.0-3.33)$ & 3 & 1.7 & & \\
\hline Moderate (3.34-6.67) & 107 & 59.4 & & \\
\hline High $(6.68-10.0)$ & 170 & 38.9 & & \\
\hline
\end{tabular}

Table 14: Relationship between QOWL and work performance among AAE

\begin{tabular}{lll}
\hline Variables & $\mathrm{r}$ & $\mathrm{p}$ \\
\hline Individual and family life & 0.758 & 0.000 \\
Job satisfaction & 0.597 & 0.000 \\
Personnel health and well being & 0.587 & 0.000 \\
Interpersonal relationship in the organization & 0.518 & 0.000 \\
Work environment & 0.498 & 0.000 \\
Safety and security in the organization & 0.456 & 0.000 \\
Remuneration & 0.359 & 0.000 \\
Organizational policies and management style & 0.328 & 0.000 \\
Organizational support & 0.306 & 0.000 \\
\hline
\end{tabular}

It can be concluded that the relationship between individual and family life $(r=0.758)$ portrays a positive and high relationship, while job related $(\mathrm{r}=0.597)$, personal health and well being $(\mathrm{r}=0.587)$, interpersonal relationship in the organization (0.518), work environment $(r=0.498)$ and safety and security in 
the organization $(r=0.456)$ have positive and moderate relationship with work performance. The other three aspects of QOWL studied, which are remuneration $(\mathrm{r}=0.359)$, organizational policies and management style $(r=0.328)$ and organizational support $(0.306)$ were found to have positive and low relationship.

Multiple linear regression was employed in order to reveal the significant contribution among the predictors variable in explaining work performance. From the multiple linear regression done, it can be concluded that five independent variables provide the best prediction for work performance and explained about $65 \%$ of variation in work performance. These five variables are individual and family life, job satisfaction, organizational policy and management style, work environment and remuneration.

From the data provided in Table 15, it can be noted that AAE who are satisfied with their individual and family life, are more likely to have better work performance. This is in line with number of previous studies that focus on relationship between individual and family life with work performance. Winberg and Mauksch (2007); Etaugh and Poertner (1992) and Huario-Mannilla (1991) have proved that certain individual and family factors did affect the work performance. This study also has demonstrated that job satisfaction is one of the factors for work satisfaction. This is expected as there are growing number of literatures that associated job satisfaction and work performance. Studies accomplished by Wright et al. (2007); Bauer (2004); Schleicher et al. (2004); Judge et al. (2001) and Hochwarter et al. (1999) has noted that job performance has significant relationship with work satisfaction. Based on their studies, if the employee job satisfaction reaches at its best level, organization will have bigger opportunity to achieve higher flexibility, higher product quality and more importantly higher performance. Their studies concluded that the relationship between job satisfaction and job performance is complex and likely cyclical. Studies have shown that increased job satisfaction leads to increased motivation, less apathy and better worker mood, all of which increase efficiency and overall quality of work performance.

Table 15: QOWL factors that contribute to work performance using multiple linear regression

\begin{tabular}{lccc}
\hline Independent variables & Standardize beta & $\mathrm{t}$ & $\mathrm{p}$ \\
\hline Constant & & 6.230 & 0.000 \\
Individual and family life & 0.610 & 10.066 & 0.000 \\
Job satisfaction & 0.388 & 5.234 & 0.000 \\
Organizational policy and & & & \\
management style & -0.199 & -2.718 & 0.007 \\
Work environment & 0.139 & 2.223 & 0.028 \\
Remuneration & -0.147 & -0.2174 & 0.031 \\
\hline $\mathrm{R}=0.803 ; \mathrm{R}^{2}=0.645 ; \mathrm{R}$ adjusted $=0.635 ; \mathrm{F}=63.263 ; \mathrm{sig}=0.000$
\end{tabular}

Organizational policy and management style were also found to lay an important role in influencing work performance of the employees as stressed by Tella et al. (2007). Study done by Tella et al. (2007) further strengthen the studies done by Mastura et al. (2006) and Shibata et al. (1991) who claimed that organization management has tremendous effect in determining their work performance. For them, in order to create more effective and productive employee, organization will have to move to more organic and participative management style. Work environment also found to have significant and positive relationship with work performance. To have a positive work environment is one of the important elements for achieving organizational success. The results found in this study are consistent with what have been done earlier by Westerman and Simmons (2007) and Judge and Cable (1997).

Other important aspect that must not be denied its importance in intensifying work performance is the remuneration aspect. Better remuneration schemes can be a catalyst of an organization to intensify their employees work performance thus increasing the organization productivity. Things such as salary, bonuses, salary increment, medical benefits and allowances are indeed will sway employees motivation to perform more in their tasks. Doloi (2005); Ajila and Abiola (2004) and Nwachukwu (1994) through their researches have proved that remuneration will boost employees performance as they emphasized that efforts to provide the best remuneration scheme must be initiated in cultivating workers interests towards their job so as to make them happy in giving their best to the work.

\section{CONCLUSION}

Results presented obviously prove that quality of work life elements are indeed important determinants for work performance. Agriculture agencies in Malaysia have to conduct and encourage their employees to attend any course or seminar that are related to individual and family life management because it has been proved that this element is the higher contributor to work performance among AAE. Agriculture agencies have to take the responsibility in intensifying aspects of job satisfaction, organizational policy and management style, work environment and remuneration. Conversely, more open, employee friendly and tolerate organization policy has proved to enhance employee work performance as stressed by Tella et al. (2007) and Mastura et al. (2006). It is also the responsibility of agriculture agencies to ensure that 
work environment in their department, board or institute is always in harmony. Any damage regarding the technical aspects within the office should not be taken for granted and must be repaired instantaneously, thus it can produce comfortable environment for the employee to uplift their work performance. Remuneration is indeed an important aspect for work performance. Agriculture agencies must think of a way that can enhance the remuneration scheme. One of the alternatives here is to enhance the bonus that they received once a year. Support staff must be allocated more over time work so that they can generate extra money while the management staff should be left the ban for them doing part time work.

\section{REFERRENCES}

Ajila, C. and A. Abiola, 2004. Influence of reward on workers performance in an organization. J. Soc. Sci., 8: 7-12. http://www.krepublishers.com/02Journals/JSS/JSS-08-0-000-000-2004-Web/JSS08-1-001-084-2004-Abst-PDF/JSS-08-1-007-0122004-Ajila/JSS-08-1-007-012-2004-Ajila.pdf

Bauer, T.K., 2004. High performance work place practices and job satisfaction: Evidence from Europe. ftp://ftp.iza.org/dps/dp1265.pdf

Candace, W., A. Vanc and G. Stafford, 2008. Internal communication, information satisfaction and sense of community: The effect of personal influence. http://www.instituteforpr.org/files/uploads/White_ Vanc_Stafford.pdf

Cascio, W.F., 1992. Managing Human Resources: Productivity Quality of Work Life Profits. McGraw Hill Inc., New York, ISBN: 9780072987324.

Davies, D., R. Taylor and L. Savery, 2001. The role of appraisal, remuneration and training in improving staff relation in western Australian accommodation industry: A comparative study. J. Eur. Ind. Train., 25: 366-373. DOI: 10.1108/EUM0000000005837

Doloi, H., 2005. Analysis of incentivised remuneration schemes in construction industries. Proceeding of the 22nd International Symposium on Automation and Robotics in Construction, Sept. 11-14, Ferrara Italy, pp. 1-7

Etaugh, C. and P. Poertner, 1992. Perception of women: Influence of performance, marital and parent variables. J. Sex Roles, 26: 311-321. DOI: 10.1007/BF00289914

Ezra, M. and M. Deckman, 1996. Balancing work and family responsibilities: Flextime and child care in the federal government. J. Publ. Admin. Rev., 56: 174-179.
Goris, J.R., B.C. Vaught and J.D. Pettit, 2000. Effects of communication direction on job performance and satisfaction: A moderated regression analysis. J. Bus. Commun., 37: 348-368. DOI: 10.1177/002194360003700402

Hardin, E., 1960. Computer automation, work environment and employee satisfaction: A case study. J. Ind. Labor Rel. Rev., 13: 559-567. http://www.jstor.org/pss/2520205

Hersey, P. and K.H. Blanchard, 1993. Leadership style: Attitudes and Behaviors, Prentice Hall, Englewood Cliffs, New Jersey. http://www.scribd.com/doc/6893750/Hersey-andBlanchard-Leadership-Style-Attitudes-and-Beh

Hochwarter, W.A., P.L. Perrewe, G.R. Ferris and R.A. Brymer, 1999. Job satisfaction and performance: The moderating effects of value attainment and affective disposition. J. Vacation. Behav., 54: 296-313. DOI:10.1006/jvbe.1998.1659

Huario-Mannilla, E., 1991. Satisfaction with family work, leisure and life among men and women. J. Hum. Relat., 24: 585-601. DOI: 10.1177/001872677102400612

Hutchinson, S. and M.L. Garstika, 2006. Sources of perceived organizational support: Goal setting and feedback. J. Applied Soc. Psychol., 26: 1351-1366. DOI: $10.1111 / \mathrm{j} .1559-1816.1996 . t b 00075 . x$

Kim, C.W., M.L. McInerney and R.P. Alexander, 1999. Job satisfaction related to safety performance: A case from manufacturing firm. J. Coastal Bus., 1: 63-71. http://www.coastal.edu/business/cbj/pdfs/safety.pdf

Litterst, J.K. and B. Eyo, 1982. Gauging the effectiveness of formal communication programs: A search for the communication-productivity link. J. Bus. Commun., 19: 15-26. DOI: 10.1177/002194368201900202

Luchak, A.A. and I.R. Gellatly, 2002. How pension accrual affect job satisfaction. J. Labor Res., 23: 146-162. DOI: 10.1007/s12122-002-1023-5

Madlock, P.E., 2008. The link between leadership style, communicator competence and employee satisfaction. J. Bus. Commun., 45: 61-78. DOI: 10.1177/0021943607309351

Martzler, K. and B. Renzl, 2007. Assessing asymmetric effects in the formation of employee satisfaction. J. Tourism Manage., 28: 1093-1103. DOI: 10.1016/j.tourman.2006.07.009

Mastura, J., T. Ramayah and Z. Zainurin, 2006. Work satisfaction and work performance: How project managers in Malaysia perceived it? Proceeding of the Conference on Academy of World Business, Marketing and Management Development, July 1013, Paris, France, pp: 1305-1313. 
Mazerolle, S.M., J.E. Bruening, D.J. Casa and L.J. Burton, 2008. Work-family conflict, part 2nd: Job and life satisfaction in national collegiate athletic association division I-A certified athletic trainers. J. Athletic Train., 43: 513-522. PMID: PMC2547871

Darlene, M.O., and W.C.Borman, 1989. More evidence on relationships between the work environment and job performance. J. Hum. Perform., 2: 113-130. DOI: $10.1207 /$ s15327043hup0202_3

Mulvaney, L.H., J.W. O'Neill, J.N. Cleveland and A.C. Crouter, 2006. A model of work-family dynamics of hotel manager. J. Tourism Res., 34: 66-87. DOI: 10.1016/j.annals.2006.07.002

Nwachukwu, C.C., 1994. Effective leadership and productivity. Evidence from national survey of industrial organization. Afr. J. Stud. Soc. Iss., 1: 38-46.

Ogunjimi, L.O., C.A. Ajibola and L.U. Akah, 2008. Comparative analysis of stressor on job performance of public and private health workers in Calabar, Nigeria. J. Int. NGO., 4: 97-103.

Okpara, J.O., 2004. The impact of salary differential on managerial job satisfaction: A study on gender gap and its implication for management education and practices in a developing economy. J. Bus. Dev. Nations, 8: 66-92. http://www.ewp.rpi.edu/jbdn/jbdnv803.pdf

Oshagbemi, T., 2000. Satisfaction with co-workers' behavior. J. Employee Relat., 22: 88-106. DOI: 10.1108/01425450010310815

Pettit, J.D., J.R. Goris and B.C. Vaught, 1997. An examination of organization communication as a moderator of the relationship between job performance and job satisfaction. J. Bus. Commun., 34 : 81-98. DOI: 10.1177/002194369703400105

Phattanacheewapul, A. and P. Ussahawanitchakit, 2008. Organizational justice versus organizational support: The driven-factors of employee satisfaction and employee commitment on job performance. J. Acad. Bus. Econ., 2: 22-30

Piqueras, C., 2006. Improving employee satisfaction and well being using emotional intelligence. http://www.coachingvalencia.es/catalogo/archivos/ 9_archivos/emotional\%20intelligence $\% 20$ and $\% 20$ well-being.pdf

Porter, L.W. and E.E. Lawler, 1968. Managerial Attitudes and Performance. Irwin-Dorsey, Homewood, Illinois, pp: 209. http://openlibrary.org/b/OL22093402M/Managerial _attitudes_and_performance

Schleicher, D., J. Watt and G. Greguras, 2004. Reexamining the job satisfaction-performance relationship: The complexity of attitudes. J. Applied Psychol., 89: 167-177.
Shibata, G., D. Tse, I. Vertinski and D. Wehrung, 1991. Do norms of decision making style, organizational design and management style affect performance of Japanese firms. An exploratory study of medium and large firms. J. Manage. Dec. Econ., 12: 135-146. DOI: 10.1002/mde.4090120207

Sloane, P. and H. Williams, 1996. Are overpaid workers really unhappy? A test of the theory of cognitive dissonance. J. Labor, 10: 3-15. DOI: 10.1111/j.1467-9914.1996.tb00077.x

Spytak, J.M., D.W. Marsland and D. Ulmer, 1999. Job satisfaction: Putting theory into practice. Family practice management. http://www.aaafp.org/fpm/991000fm/26.html

Tella, A., C.O. Ayeni and S.O. Popoola, 2007. Work motivation, job satisfaction and organizational commitment of library personnel in academic and research libraries in Oyo State, Nigeria. J. Library Philosophy Pract., 4: 1-16.

Vanhala, S. and K. Tuomi, 2006. HRM, company performance and employee well being. J. Manage. Rev., 17: 241-255. ISSN 1861-9916

Vloisky, R.P. and F.X. Aguilar, 2009. A model of employee satisfaction: Gender differences in cooperative extension. J. Ext., 47: 1-15.

Wan, H.L., 2007. Remuneration practices in chemical industry in Malaysia: The impact on employee satisfaction. J. Compensat. Benefit Rev., 39: 56-67. DOI: $10.1177 / 0886368707302734$

Westerman, J.W. and B.L. Simmons, 2007. The effects of work environment on the personalityperformance relationship. http://www.entrepreneur.com/tradejournals/article/ 166092745.html

Winberg, R.B. and L.B. Mauksch, 2007. Examining-offamily origin influences in life at work. J. Marit. Fam. Ther., 17: 233-242.

Witt, L.A. and D.S. Carlson, 2006. The work family interface and job performance: Moderating effects of conscientiousness and perceived organizational support. J. Occup. Health Psychol., 11: 343-357. http://psycnet.apa.org/index.cfm? 2006-13308005\&CFID $=4869089 \&$ CFTOKEN $=92993649$

Wright, T., R. Cropanzano and D. Bonett, 2007. The moderating role of employee positive well being on the relation between job satisfaction and job performance. J. Occup. Health Psychol., 12: 93-104. http://www.ncbi.nlm.nih.gov/pubmed/17469992 